総

説

\title{
泳動電着法を用いる炭素材料膜の作製と応用
}

\author{
宇井 幸一的1，小浦 延幸的2 \\ 41 岩手大学大学院工学研究科フロンティア材料機能工学専攻, † 020-8551 盛岡市上田 4-3-5. \\ 山2 東京理科大学理工学部工業化学科, 干 $278-8510$ 野田市山崎 2641.
}

\section{Fabrication and Application of Carbon Material Films by Electrophoretic Deposition Method}

\author{
Koichi $\mathrm{Ui}^{\text {is } 1}$ and Nobuyuki Koura ${ }^{\text {出 } 2}$ \\ 47 1 Frontier Materials and Function Engineering, Graduate School of Engineering, Iwate University, 4-3-5 Ueda, Morioka 020-8551, Japan. \\ ${ }^{4} 2$ Department of Pure and Applied Chemistry, Faculty of Science \& Technology, Tokyo University of Science, \\ 2641 Yamazaki, Noda 278-8510, Japan.
}

Received October 15, 2007

\begin{abstract}
SYNOPSIS
We have ever proposed to prepare the highly functional material films by using an electrophoretic deposition (EPD) method. In this review, we have utilized the EPD process to fabricate the binder-free carbon negative electrodes for lithium ion secondary batteries; these electrodes were fabricated without mixing a binder. Powdered active materials are usually used for the electrode of lithium ion secondary batteries. The binder is used to form it as an electrode but is not concerned in charge-discharge reaction directly. Therefore, if it is not used for the electrode fabrication, it leads to high energy density of a battery. Artificial graphite powders could be deposited on the anode substrate by the EPD method. Smooth and uniform deposit could be obtained. It was shown clearly that the binder-free artificial graphite film functioned as the negative electrode for lithium ion secondary batteries. In addition, a co-deposited film consisting of activated carbon and Ketjenblack powder particles was investigated as the electrode for capacitor cells. It was found that the co-deposited film fabricated by adding polyvinylidine difluoride as a binder to the EPD bath operated successfully as it. From these results, it is concluded that the EPD method can be applied as the carbon electrode fabrication process.
\end{abstract}

KEY WORDS

electrophoretic deposition, lithium ion secondary battery, carbon negative electrode, electric double layer capacitor, activated carbon

\section{1 はじめに}

電気泳動とは, 分散媒中にコロイドや粒子 $(0.2 \sim 40 \mu \mathrm{m})$ が 分散・懸濁された状態にあるとき，その溶媒中に 2 本の電極 を差し込み, 両極間に電圧を印加すると, 帯電した粒子が電 位勾配によって，粒子の帯電と反対の電位を有する電極へ 向って移動する現象である．この現象は，鉱物資源として重 要な粘土，石油，ならびに金属イオンなどを分離精製するた めの技術を研究していたソビエトの物理学者Reussによって, 1807 年に発見されたものである ${ }^{1)}$. Reuss は, U字管に粘土懸 濁液を入れ，2つの電極を用いて值流を流すことで，カソー ド側の水位が上昇し, 粘土粒子がアノードに泳動することに より, 効率よく粘土粒子が分離することを示した．これが電 気浸透現象と電気泳動現象を述べた初めての報告である.

この電気泳動現象を利用したコーティング方法を泳動電着
法という．例として, 粒子が正に帯電し, 陰極(カソード)に 堆積する場合の原理をFig.1に示す. 粒子の帯電(ゼー夕電位) が 10〜 $50 \mathrm{mV}$ の場合, 水溶液系における粒子の移動度は, 室 温において $8.0 \times 10^{-5} \sim 3.9 \times 10^{-4} \mathrm{~cm} \mathrm{~s}^{-1}$ なので, 単一イオンの 物質移動速度と同程度といえる. また， $10^{10}$ 個以上の原子か ら構成される粒子の周りに帯電している電荷は $10^{4} \sim 10^{5}$ 個程 度である例もあり, 1 原子の析出に 1 ６個の電荷移動を要す るイオンからの電析に比べ, 析出のための通電量として遥か に有利である.これらのことから, 泳動電着法は電気めっき よりはるかに効率の良いコーティング方法といえる.

泳動電着法はコーティング技術として, 次のような長所を 有する.すなわち, (1)泳動電着に適用する粒子の段階で, 膜 の組成を決めておくことができること, (2)均一でち密な粒子 堆積層の形成が可能であること, (3)成膜速度が速く, また, 厚 


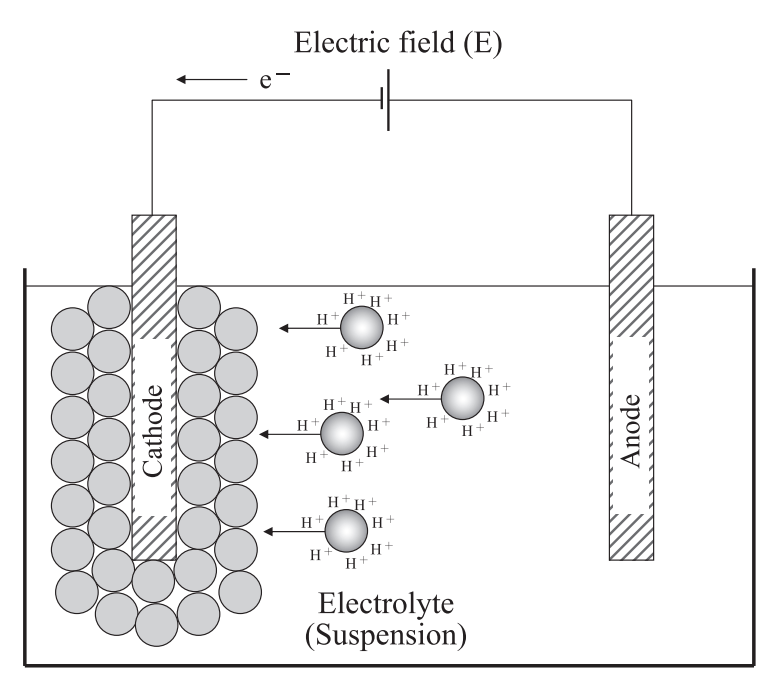

Fig.1 Principle of electrophoretic deposition method (The case of positive charging particle).

膜の作製が可能であること(例えば, 数 10 秒で数 $100 \mu \mathrm{m}$ の厚 膜が得られる場合もある. ), (4)膜厚を印加電圧や電着時間で 容易に制御できること, (5)任意形状の基板上に成膜が可能で あること, (6)工程数が少なく, 装置が簡便であること, (7)非 水系分散媒(有機溶媒)を用いれば, 数 $100 \mathrm{~V}$ といった高電圧 を印可する場合でも電流值が極めて小さく, 省電力性に優れ ていること, 8水系分散媒を使用することで, 環境低負荷型 製造プロセスを確立できることなどが挙げられる. 一方, 短 所としては, (1)基板が電子伝導性を有する必要のあること, (2)電着中に基板近傍から気体の発生が起こることがあり, 成 膜を妨げる場合があること, (3)堆積した膜の強度に課題が残 ることなどが挙げられる.よって，これらの短所を克服する ような工夫が必要である.

\section{2 泳動電着機構}

泳動電着法は, 水系または非水系溶媒中に粉体を分散させ た電着浴(懸濁液)中に, 一対の電極を挿入し, 外部より電気 的作用 (電圧)を加えることで, 電着浴中に電位勾配を発生さ せ, 粒子の帯電と反対の電位を有する電極表面に粒子を移動 (電気泳動)させて, 堆積させる手法である. すなわち, 電着 浴中で粒子表面が正に帯電していればカソードに, また, 負 に帯電してい狄ばアノドに堆積する(Fig.2). 泳動電着のプ ロセスは, 主に次の3つからなる. (1)電着浴中の粒子の帯電, (2)電気的作用による帯電粒子の電気泳動, (3)電極表面への粒 子の堆積・凝集である. そこで, 各々のプロセスのポイント について述べる.

まず，粒子の帯電は，一般的に次のいずれかが主な要因に なる場合が多いと考えられる. (i) 粒子表面にプロトン, 水酸 化物イオンなどの電位決定イオンが存在する場合, あるいは これらのイオンを粒子表面に吸着させる場合 (金属酸化物の 他, チッ化物, 炭化物, ケイ化物など), (ii) 粒子表面および

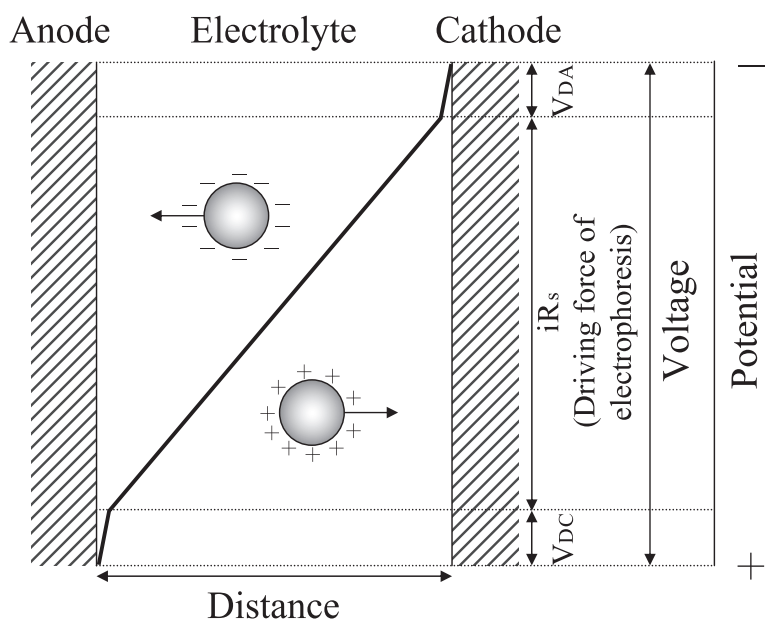

Fig.2 Ideal potential slope of electrophoretic deposition and electrophoresis of charging particle. $\mathrm{V}_{\mathrm{DC}}, \mathrm{V}_{\mathrm{DA}}$ : Cathode and anode deposited potential, I: Current, $R_{s}$ : Resistivity of solution.

浴中に電位決定イオンがなく, 外部からイオン性の界面活性 剤などを添加し，ての界面活性剤などが粒子表面に吸着する ことにより帯電する場合 (チッ化ホウ素, PTFE, フッ化カー ボン, 有機物など) である.

そこで, 粒子表面に電荷をもたせる例として, 研究報告が 最も多い酸化物粒子について紹介する.分散媒としては水系, アルコール系, ケトン系など, 各々の粒子に最適なものが使 用されているが, 本稿では, 分散媒として極性を有する非水 系溶媒のアセトンを用いて, これに少量の水とヨウ素を添加 した浴に, 酸化物粒子を分散させた例について述べる.アセ トンには, ある一定の割合のエノール体が含まれている(ケ トーエノール互変異性). このアセトンに少量の水とヨウ素を 添加すると, それらの触媒作用によって, ある程度ケトーエ ノール互変異性が促進され(式(1)), この溶液中のエノール体 とヨウ素が反応し, プロトンを生じる (式(2) $)^{2,3)}$. 式(2)の反 応によりエノール体が消費されるので, 式 (1)の平衡がアセ トンのエノール化を促進する右にシフトし, さらにヨウ素と 反応して, プロトンの生成を促進する.これらのイオンの生 成により, 浴の導電率は上昇し, ヨウ素添加量に依存したあ る一定値に達する ${ }^{3)}$.

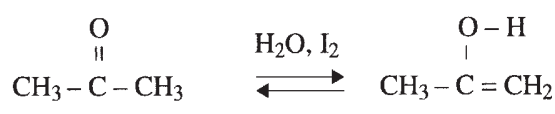

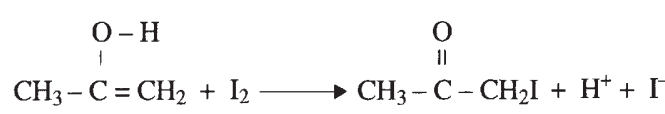

この状態の浴中に酸化物粒子を添加すると, Fig.1に示すよう にプロトンが粒子表面に吸着して, 粒子が正の電荷を帯びる と考えられる4).

次に, 2 つの電極間に電圧を印加することによって, 電着 浴の沖合いで物質移動に必要な電位勾配をもつことになり, 
電着浴中で帯電した粒子が, この電位勾配によって電気泳動 を始める ${ }^{5)}$.このとき, 粒子/溶液界面の電気二重層では, 外 部 Helmholtz 面の溶液は少なくとも粒子に固定され, その外 部の Gouy-Chapmann 層のどこかに流動の起こり始める界面( 滑り面)を生じる. 沖合いでの溶液電位を基準としたときの この滑り面の電位をゼー夕電位という.この分散媒に与えら れた電場を駆動力とする粒子の電気泳動速度 $\mathrm{v}\left(\mathrm{m} \mathrm{s}^{-1}\right)$ は, Helmholtz-Smoluchowski の式で表わされる(式 (3) $)^{6}$.

$$
\mathrm{v}=\varepsilon_{\mathrm{r}} \varepsilon_{0} \zeta \mathrm{E} / \eta
$$

ここで, $\varepsilon_{\mathrm{r}}$ は溶媒の比誘電率 $(-), \varepsilon_{0}$ は真空の誘電率 $\left(\mathrm{F} \mathrm{m}^{-1}\right)$, らは粒子の界面動電位 (ゼ一夕電位) (V), $\mathrm{E}$ は印加電圧 $\left(\mathrm{V} \mathrm{m}^{-1}\right)$, $\eta$ は溶媒の粘性率 $(\mathrm{Pa} \cdot \mathrm{s})$ である. したがって, ゼ一夕電位の 值が小さかったり,この電位勾配が不十分な場合, 荷電粒子 が電気泳動しなくなる, あるいは十分な電気泳動速度が得ら れなくなる等の理由により, 密着性の悪い膜が形成されるこ とになる.このことから, 成膜には電解質濃度の調節などに よるゼー夕電位の制御や, 電場の制御によって, 電気泳動速 度をコントロールすることが重要な因子となってくる.

また, 泳動電着量について, 電着を行なう電極の表面積を $\mathrm{S}\left(\mathrm{m}^{2}\right)$, 電着量を $\mathrm{m}(\mathrm{g})$ とすると, 単位表面積当たりの電着量 $\mathrm{m} / \mathrm{S}\left(\mathrm{g} \mathrm{m}^{-2}\right)$ は, 次式によって表わされる.

$$
\mathrm{m} / \mathrm{S}=\alpha \mathrm{Cvt}
$$

ここで, $\alpha$ は電極表面における凝析係数(-), C は電着浴中の 粒子濃度 $\left(\mathrm{g} \mathrm{m}^{-3}\right), \mathrm{t}$ は電着時間 $(\mathrm{s})$ である. したがって, 電着 量は式(3),(4)より, 次式によって表される.

$$
\mathrm{m} / \mathrm{S}=\alpha \mathrm{Ct} \varepsilon_{\mathrm{r}} \varepsilon_{0} \zeta \mathrm{E} / \eta
$$

実際に, 印加電場あるいは電着時間に対する電着量の関係は, 式 (5)の関倸に近くなることが多い. 実際の場合, 粒子の材 質, 形態や粒度分布, 分散媒や添加剤の種類など, 電着条件 に影響を及ぼす様々な因子が考えられるが, 帯電が電位決定 イオンの吸着に起因するものであれば, 電極反応の本質は同 じであり, その反応機構はFig.3のように, 帯電した粒子が電 着膜上に衝突すると, 粒子に吸着したプロトンが電着膜の粒 子間を拡散し, 電極基板上で $\mathrm{H}_{2}$ 発生の電極反応を起こすもの と考えられている4).

\section{3 泳動電着法を用いた炭素材料膜の作製}

以上のような特徵を有するため, 酸化物, ガラス, 蛍光体, 金属化合物, 高分子など, 数多くの材料の成膜について研究 されてきた. しかし, 炭素材料についての報告例は少なく, カーボンブラックフ, フラーレンのクラスター8)もしくは誘導 体"9),カーボンナノチューブ10,11)などの成膜に関するくらいで ある. 一方で, プロセスの改善としては, 従来の電気的作用 (電場) に加え, 磁場 12,13$)$ などの外部場を組み込んで, 粒子の 堆積状熊をより精密にコントロールしようとする研究や、ゾ ルーゲル法と泳動電着法を組み合わせたゾルーゲル電気泳動

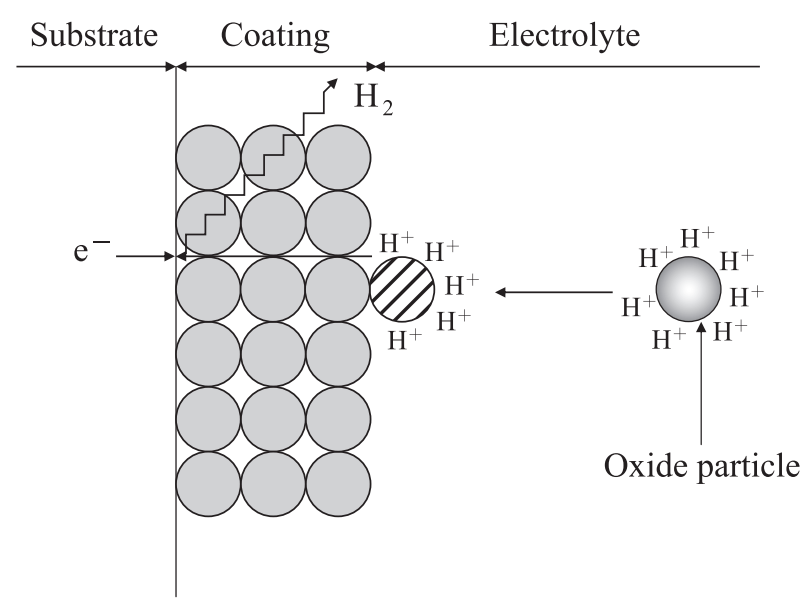

Fig.3 Schematic model for the deposition mechanism of the oxide particles charged by adsorbed $\mathrm{H}^{+}$.

電着法 ${ }^{14,15)}$ も提案されている.

そこで本稿では,「電気化学エネルギー変換・貯蔵デバイス 用炭素電極の製造プロセスへの泳動電着法の適用」と題して, 我々の研究成果を中心に紹介させていただく.

\section{4 電気化学エネルギー变換・貯蔵デバイス用炭素電極の 製造プロセスへの泳動電着法の適用}

これまで金村・濱上らのグループより，泳動電着法を用い たリチウムイオン二次電池用電極の製造方法とその電極特性 が報告されている ${ }^{16-199}$. リチウムイオン二次電池用正極とし $\tau$, 活物質 $\mathrm{LiCoO}_{2}$, 導電凨ケッチェンブラック, バインダー (結着片)ポリテトラフルオロエチレンを共析させて正極を作 製し, 塗布法で作製した電極よりも良好な特性を示すことが 報告されている.

一方, これまで我々は泳動電着法を用いて, 酸化物超伝導 体 ${ }^{3,46)}$, ゼオライト ${ }^{200}$, 強誘電体 ${ }^{21)}$ などの成膜に取り組んで きたが，いずれもバインダーを用いる必要はなかった。リチ ウムイオン二次電池用負極には多様な炭素材料が用いられて おり,これを成形して電極にするために, 種々のバインダー が使用されている. その一般的な作製方法としては, まずバ インダーとなるポリフッ化ビニリデン(PVdF)などを有機溶剤 (N-メチルピロリドン, NMP)などに溶解し, それに粉末状の 炭素材料を混合し, 所定の粘度に調整したペーストを調製す る.コーティング機などを用いて，これを金属集電体(銅䈃) 上に塗布し，乾燥によって溶媒を揮発させ，プレス成形する 方法である ${ }^{22)}$. バインダーの主な役割は, (1)活物質粉末の ペースト化, (2)活物質粒子と集電体の接着, (3)活物質粒子同 士の結着などに大別される. しかし, バインダーは電極反応 に直接関与しないので, これを減らすか, もしくは使用しな ければ, 電池のさらなる高エネルギ一密度化に効果をもたら すと考えられる.リチウムイオン二次電池用負極の製造プロ セスとしての比較を Fig.4 亿示す. 通常の埴布法 (a)が $4 つ の$ 工程からなるのに対して, 泳動電着法(b)を利用すれば, 乾燥 


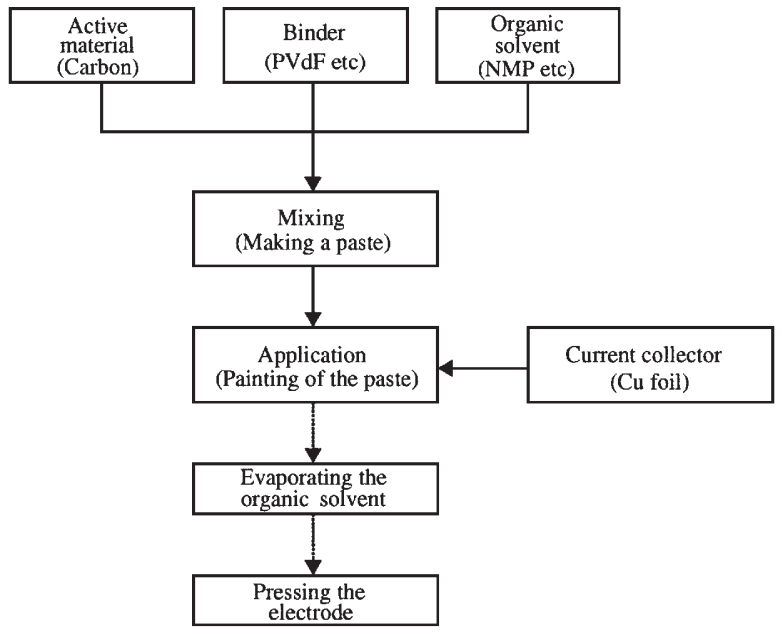

(a)

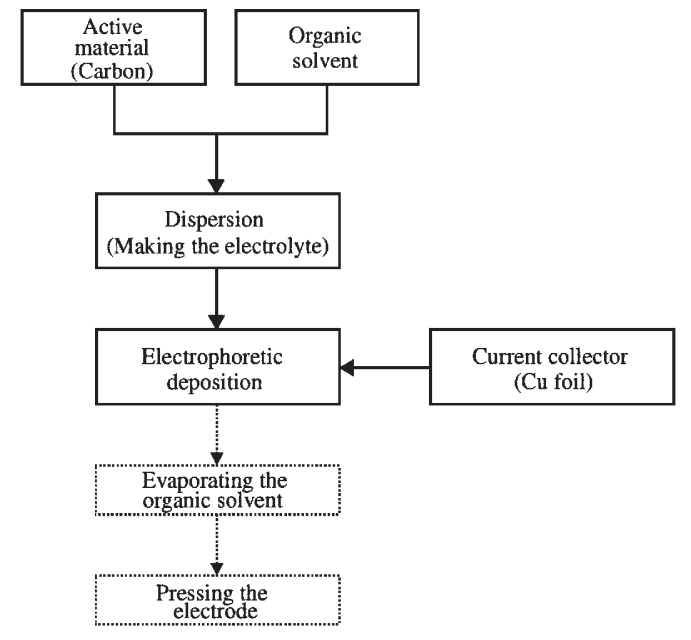

(b)

Fig.4 Comparison of manufacturing processes in negative electrode for lithium ion secondary battery. (a) application (conventional process), (b) electrophoretic deposition.

工程とプレス工程を省略できる可能性があるので, 最少 2 工 程で電極を作製でき, 低コストプロセス化を考慮しても魅力 的である. また, 泳動電着法では, 1 回の電着で集電体の両 面に成膜可能という長所も有する.

本稿では, 非水系溶媒にアセトニトリルを用いた例を紹介 する.アセトニトリル中では黒鉛粒子のゼー夕電位は負の值 を示す.この負への帯電は, 黒鉛粒子の表面に存在する表面 官能基(一COOHなど)からのプロトンの脱離によるものと考 えられる. そこで, 分散媒としてアセトニトリルを用い, 人 造黒鉛粉末 KS-6 (粒子径 $6 \mu \mathrm{m}$ 以下のものが $90 \%$ 以上) の電着 を試みたところ,アノードへの電着が可能であった.しかし, リチウムイオン二次電池の黒鉛負極では, その表面で起こる Solid Electrolyte Interface (SEI)の形成及びガス発生が, 初期不 可逆容量の最大の原因となる. ゆえに, 真の表面積が小さい, すなわち, 粒子径の大きい黒鉛粉末が用いられている23-25). そこで, KS-6と比べ, より粒子径の大きいKS-25 (粒子径 25 $\mu \mathrm{m}$ 以下のものが90\%以上)を電着させることを試みた。しか し，アセトニトリル中での KS-25 は分散性が悪く, 多くの粒 子が沈降してしまい, 電着が困難であった.

黒鉛粒子の分散性を向上させるためには, 負への帯電を強 めればよい，そこで, 表面官能基からより多くのプロトンを 脱離させることを狙い, アセトニトリルへ塩基性有機化合物 の添加を検討した. 塩基性有機化合物としてトリエチルアミ ン(TEA, $\mathrm{pKa}:$ 18.7 $)^{26)}$ を選択し, アセトニトリルに添加したと ころ, KS-25の分散性は向上した (Fig.5). また, TEAの添加 が黒鉛粒子の分散性と泳動速度に及ぼす影響を調べるため, ゼー夕電位を測定したところ, TEA添加浴中でのゼー夕電位 はさらに負へシフトし, 泳動速度は速くなることが分かった. 実際に, TEA 添加浴を用いて泳動電着を行うと,アノード電 着は可能であった. TEA添加浴および無添加浴の印加電圧と 電着量の関係を Fig.6に示す ${ }^{27)}$. TEA 無添加浴では, 印加電

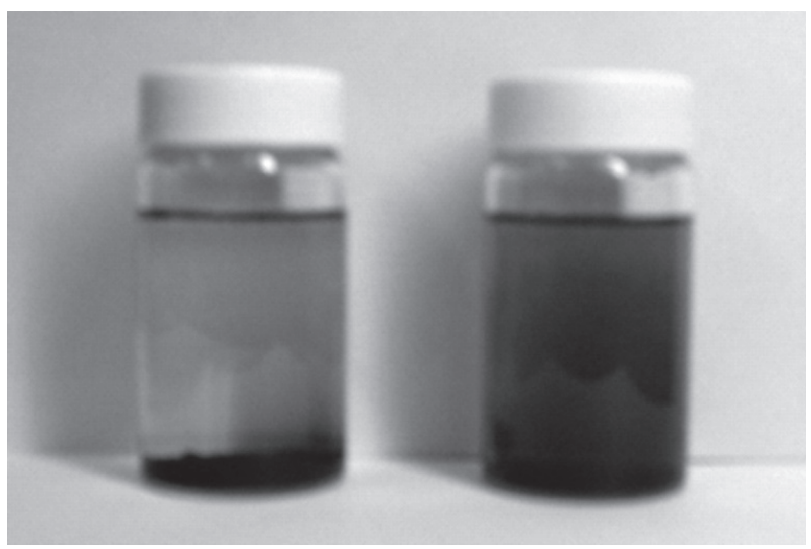

(a)

(b)

Fig.5 Dispersion state of artificial graphite particle (KS-25) in acetonitrile bath (a) without or (b) with triethylamine (7.12 $\times 10^{-3} \mathrm{~mol} \cdot 1^{-1}$ ).

圧に関わらず電着量が $1.0 \mathrm{mg} \mathrm{cm}^{-2}$ 以下なのに対し, TEA添加 浴では, 印加電圧の増加と共に電着量も増加している. また, TEA添加浴における電着時間と電着量の関係を見ても, 電着 時間の増加と共に電着量が増加している $(\text { Fig.7 })^{27)}$. このよう に,アセトニトリルを分散媒とした浴に, TEAのような塩基 性有機化合物を加えると, 粒子径の大きな黒鉛粒子の泳動電 着も可能となり, 電着時の印加電圧または電着時間を変化さ せることで, 任意の電着量の膜が得られる.

バインダーフリー人造黒鈶 $(\mathrm{KS}-25)$ 膜の接写像 $(\mathrm{a}:$ 圧延銅箔 上, b: 銀線上) を Fig.8に示す ${ }^{27)}$. この膜は基材 (浴浸漬部) 全 体を均一に覆うものであることが分かる (Fig.8 (a)). さらに, Fig.8 (b) から, この電着膜は様々な形状の基材に均一に形成 できることも分かる. 続いて, バインダーフリー人造黒鉛膜 の SEM 像を Fig.9に示す27). アセトニトリル単独浴からの電 着膜 (Fig.9 (b))より, KS-25を分散した TEA 添加浴から電着 


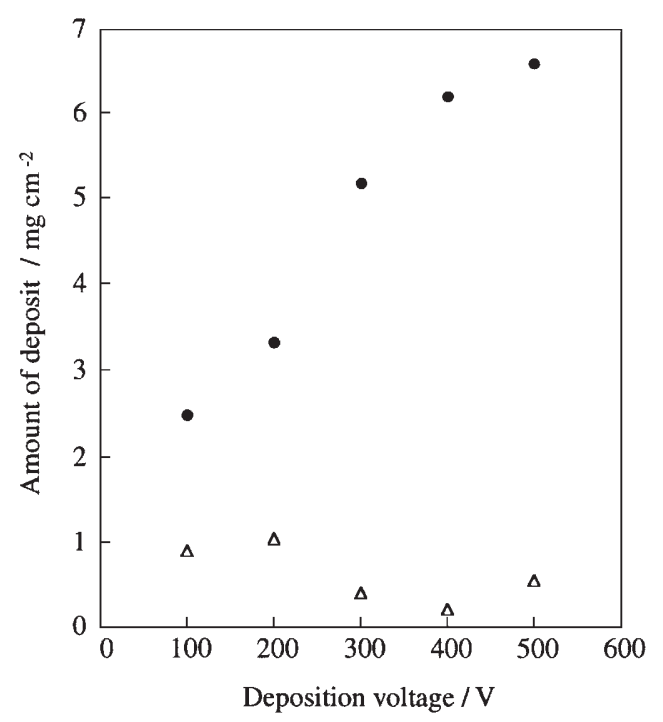

Fig.6 Relationship between deposition voltage and amount of deposit of artificial graphite particle (KS-25) from acetonitrile bath with $(0)$ or without $(\triangle)$ of TEA. TEA added: $7.12 \times 10^{-3} \mathrm{~mol} \cdot 1^{-1}$, bath temperature: $25^{\circ} \mathrm{C}$, deposition time: $20 \mathrm{~s}$.

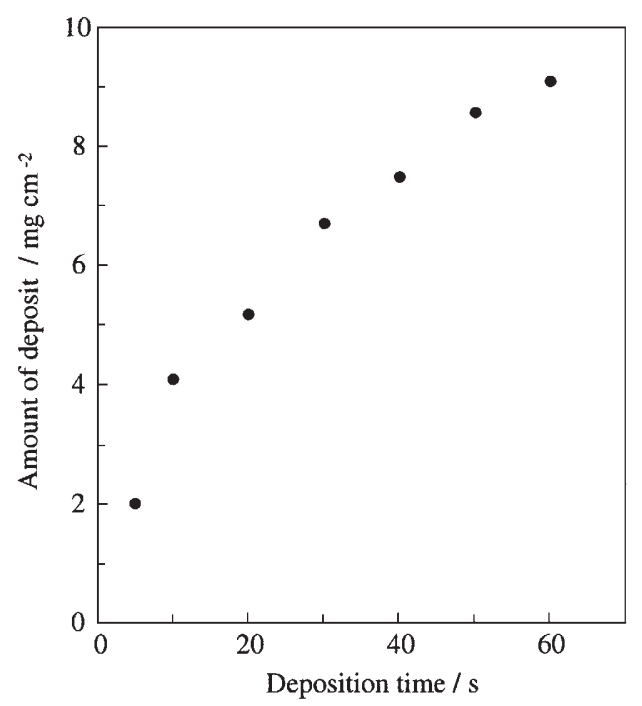

Fig.7 Relationship between deposition time and amount of deposit of artificial graphite particle (KS-25) from acetonitrile bath containing $7.12 \times 10^{-3} \mathrm{~mol} \cdot \mathrm{l}^{-1}$ TEA. Bath temperature: 25 ${ }^{\circ} \mathrm{C}$, deposition voltage: $300 \mathrm{~V}$.

膜(Fig.9(a))の方が, より大きな粒子径の黒鈶粒子が電着され たことが分かる.さらに, 各種バインダーフリー炭素材料膜 のSEM像を Fig.10に示す ${ }^{28)}$. このように, TEA添加浴を用い ることにより，(a) 天然黒鉛 (LF-18A)，(b) ソフトカーボン (FM14), (c)八ードカーボン(カーボトロンP)のいずれも, 粒子 径10 20 $\mu \mathrm{m}$ 程度の粒子からなる電着膜の作製が可能である.

次に, バインダーフリー人造黒鈶 (KS-25) (電着量: $4.53 \mathrm{mg}$ $\left.\mathrm{cm}^{-2}\right)$ の電極特性の評価として, 充放電作動試験を行った. 充 放電電流密度 $0.14 \mathrm{~mA} \mathrm{~cm}^{-2}(0.1 \mathrm{C}$ 相当, $\mathrm{C}$ は放電率 $)$ における
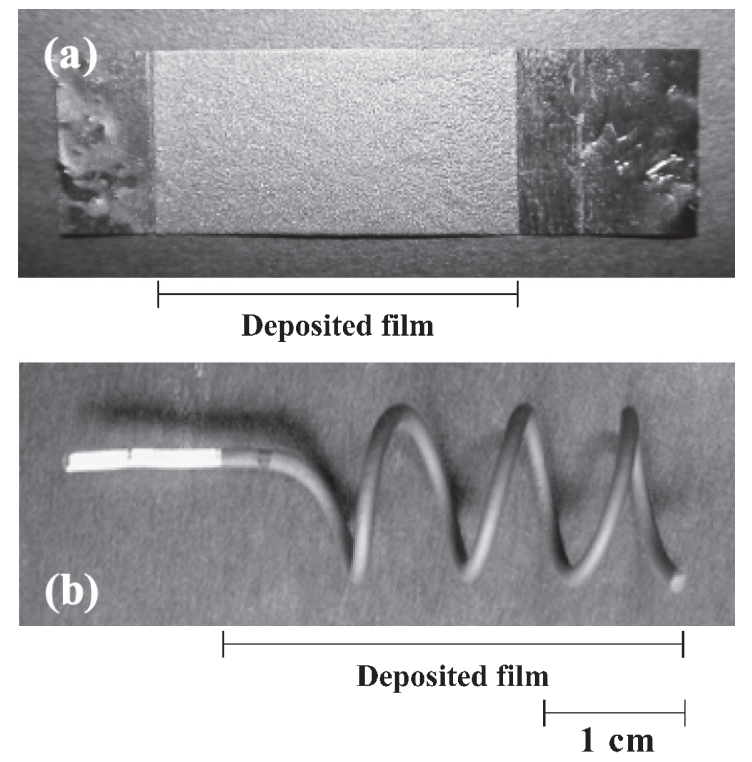

Fig.8 Photographs of artificial graphite particle (KS-25) deposited film. (a) foil substrate, (b) Ag wire substrate.
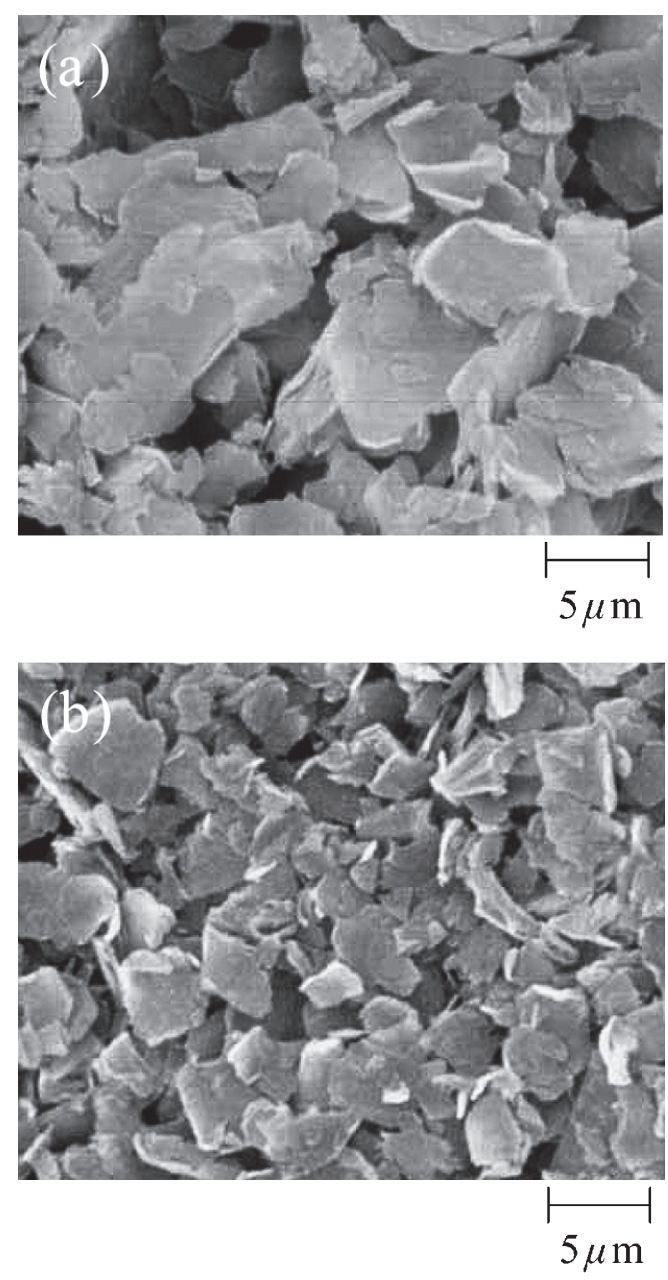

Fig.9 Surface morphologies of the artificial graphite particle deposited film. (a) deposit film obtained in the electrophoretic deposition from $5.0 \mathrm{~g} \mathrm{l}^{-1} \mathrm{KS}-25+7.12 \times 10^{-3} \mathrm{~mol} \cdot \mathrm{l}^{-1}$ TEA acetonitrile bath, (b) deposit film obtained in the electrophoretic deposition from $5.0 \mathrm{gl}^{-1} \mathrm{KS}-6$ acetonitrile bath. 


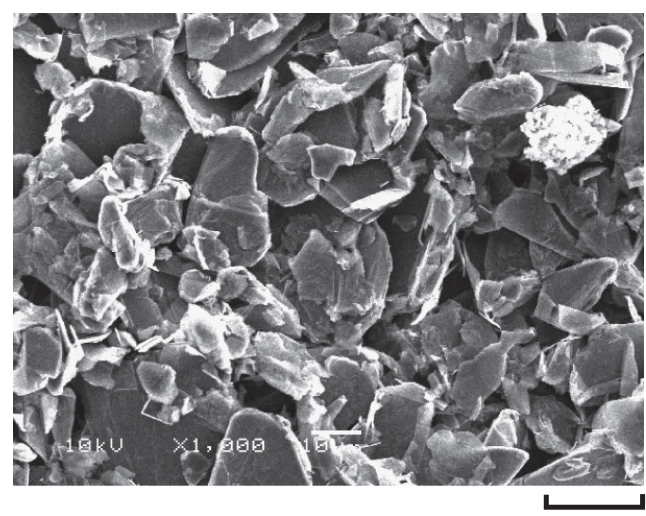

(a)

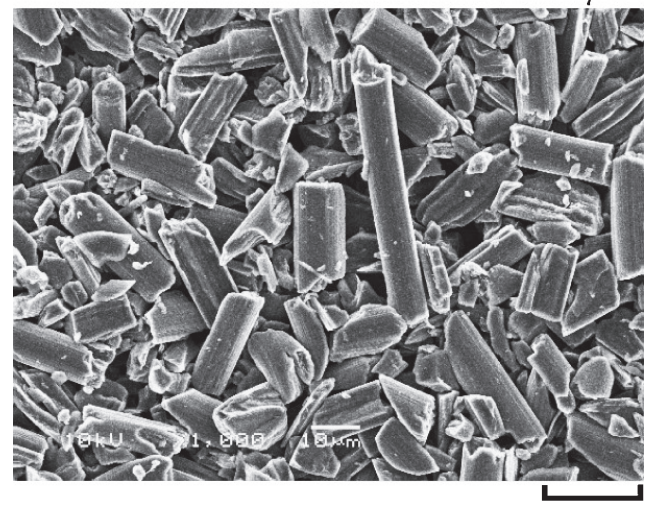

(b)

$20 \mu \mathrm{m}$

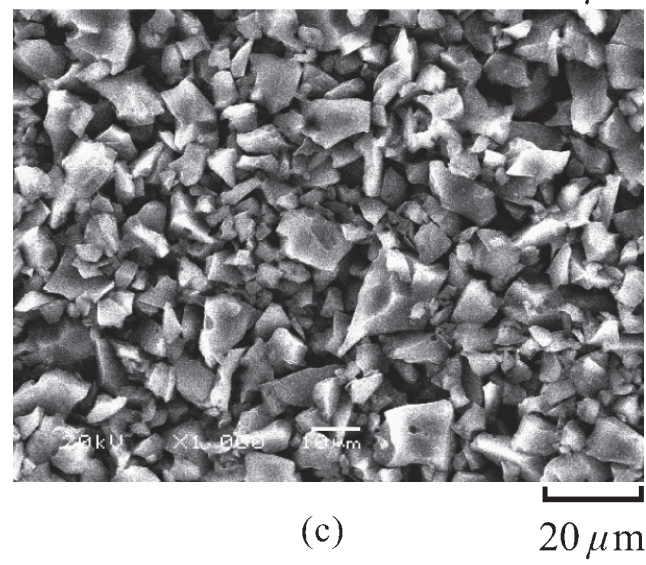

Fig.10 SEM photographs of binder-free carbon films. (a) natural graphite (LF-18A, deposition voltage $350 \mathrm{~V}$ ), (b) soft carbon (FM-14, deposition voltage $550 \mathrm{~V}$ ), (c) hard carbon (carbotron $\mathrm{P}$, deposition voltage $500 \mathrm{~V}$ ).

1サイクル目の充放電曲線を Fig.11に示す27).1サイクル目の 充電 (Fig.11 (a)，人造黒鉛への $\mathrm{Li}^{+}$イオン挿入反応に相当する カソード分極 $)$ 曲線は, $0.3 \sim 2.0 \mathrm{~V}\left(v s . \mathrm{Li}^{+} / \mathrm{Li}\right)$ 付近の電位を 示しており, $\mathrm{Li}^{+}$イオンのインターカレーション以外の反応が 起きていることが分かる，このため, 充電容量は理論容量 $\left(372 \mathrm{mAh} \mathrm{g}^{-1}\right)$ を超え, 約 $430 \mathrm{mAh} \mathrm{g}^{-1}$ を示している.これは, 電解液の還元反応が黒鈶粒子の表面で起こり, SEIが形成す るためと考えられる ${ }^{23)}$. また, 放電(Fig.11 (b)，人造黒鈶から の $\mathrm{Li}^{+}$イオン脱離反応に相当するアノード分極) 曲線は, 0.1

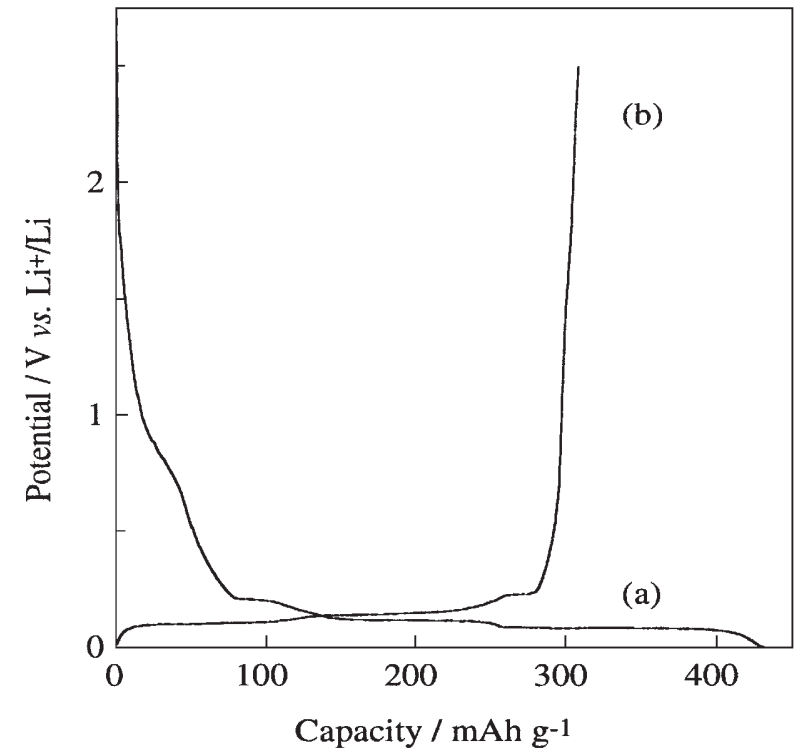

Fig.11 Charge-discharge curves of the electrophoretically fabricated artificial graphite (KS-25) electrode in the constant current charging-discharging cycle test at $0.14 \mathrm{~mA}$ $\mathrm{cm}^{-2}(0.1 \mathrm{C})$. Electrolyte: $1 \mathrm{~mol} \mathrm{dm}^{-3} \mathrm{LiClO}_{4} / \mathrm{EC}+\mathrm{DEC}$ (50: $50 \mathrm{vol} \%$ ), (a) Charge, (b) discharge.

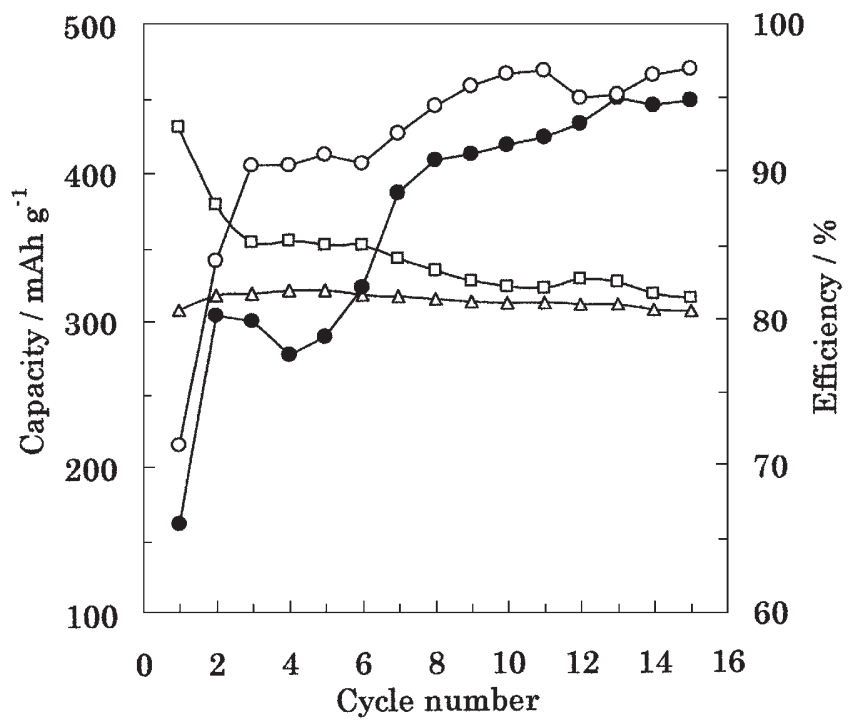

Fig.12 Cycle performance of electrophoretically fabricated artificial graphite (KS-25) electrode at $0.14 \mathrm{~mA} \mathrm{~cm}^{-2}(0.1 \mathrm{C}) . \square$ : Charge capacity, $\triangle$ : Discharge capacity, $\bigcirc$ : ChargeDischarge efficiency, : Charge-Discharge efficiency (KS-6).

$\sim 0.3 \mathrm{~V}\left(v s . \mathrm{Li}^{+} / \mathrm{Li}\right)$ 付近に, $\mathrm{Li}^{+}$イオンの脱離反応に基づく $3 \supset$ の電位平坦部が観察されており, 従来の塗布法により黒鉛粉 末とバインダーを用いて作製された黒鉛負極と同様である. ゆえに, $\mathrm{Li}^{+}$イオンの挿入・脱離反応が順調に起きていること が確認された。次に, Fig.11で示した充放電試験により得ら れたサイクル特性を Fig.12に示す27).1サイクル目の充放電 効率 $(\mathrm{Fig} .12(\mathrm{O}))$ は70\%を超えるものであり，KS-6を分散さ せたアセトニトリル浴から得られた負極(Fig.12())に比べ, 
初期における充放電効率の高いことが分かる. また，充放電 容量の值が安定した 6 サイクル以降では, 充・放電容量とも に約 $310 \mathrm{mAh} \mathrm{g}^{-1}$, 充放電効率は約 $95 \%$ を示す. 本条件で作製 した黒鉛負極は, サイクルの途中で膜の剥離师粒子の脱落は 見られなかったことから，充放電にともなう粒子の膨張・収 縮に耐えうることも確認されている.これらの結果から,ア セトニトリルに塩基性有機化合物を添加した浴を用いること で,粒子径の大きな黒鈶粒子の分散と泳動電着が可能となり, より優れた性能を持つリチウムイオン二次電池用黒鉛負極が 作製されることが示された.

これらの知見をもとにして, 電気二重層キャパシタ(キャ パシ夕電池) 用電極の作製も試みた ${ }^{29}$. 活物質として水蒸気 賦活活性炭粉末 ( $\mathrm{AC}, \mathrm{d}_{50}=12.5 \sim 17.5 \mu \mathrm{m}$, 比表面積 $\geq 2100 \mathrm{~m}^{2}$ $\left.\mathrm{g}^{-1}\right)$, 導電凨としてケッチェンブラック粉末 $(\mathrm{KB}$, 一次粒子径 $\approx$ 約 $40 \mathrm{~nm}$ ) を使用した. 電着浴に用いる分散媒として, 種及 の有機溶媒を検討した結果，アセトニトリルを用いた場合， 両方の粉末の分散状態が良好であった. そこで, アセトニト リル中での各粒子の帯電状態を調べるため, ゼー夕電位及び 移動度を測定した. AC粒子のゼー夕電位と移動度は- $85 \mathrm{mV}$, $-7.9 \times 10^{-8} \mathrm{~m}^{2} \mathrm{~V}^{-1} \mathrm{~s}^{-1}, \mathrm{~KB}$ 粒子のゼ一夕電位と移動度は-61 $\mathrm{mV},-5.6 \times 10^{-8} \mathrm{~m}^{2} \mathrm{~V}^{-1} \mathrm{~s}^{-1}$ を示した. アセトニトリル中におけ
るAC粒子と KB粒子はともに負に帯電し, その移動度はほぼ 同じであることが分かった. ゆえに，アノードへの電着を試 みたところ, ACと KBの共析膜の作製は可能であった。 しか し, 得られた共析膜の機械的強度が不足しているという問題 点があった，そこで, バインダーとして PVdFを電着浴に添 加し, 電着を試みたところ, アノード側への成膜が可能で あった. さらに, 共析膜の機械的強度は向上して, 電解液に 含浸させても共析膜の剥離は認められなかった。

電着膜の表面状態を比較するため, (a) ACのみの電着膜(印 加電圧 $600 \mathrm{~V}$ ), (b) AC と KB の共析膜 (印加電圧 $120 \mathrm{~V}$ ), (c) $\mathrm{AC}, \mathrm{KB}$ ，およびPVdFの共析膜 (印加電圧 $120 \mathrm{~V}$ ) の SEM 像を Fig.13に示す ${ }^{29}$. Fig.13 (a) に示す膜は比較的大きな AC 粒子 と小さな $\mathrm{AC}$ 粒子が電着されている. Fig.13(b)に示す共析膜

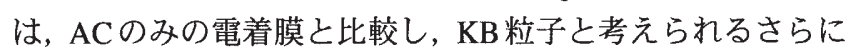
細かい粒子が共析している. Fig.13 (c)に示す共析膜は, Fig.13 (a) と (b) と比較し, より大きな粒子が電着されていることが 分かる. このことは, 電着浴に PVdFを添加することにより, 比較的大きな粒子の電着性が向上することを示唆している. Fig.13 (c) に示す共析膜 (電着量 $5.99 \mathrm{mg} \mathrm{cm}^{-2}$ ) の充放電特性を Fig.14に示す ${ }^{29}$. 放電曲線の傾きから算出された比容量は23.5 $\mathrm{Fg}^{-1}$ (一共析膜全体の質量)を示した.この值は, 市販のキャパシ

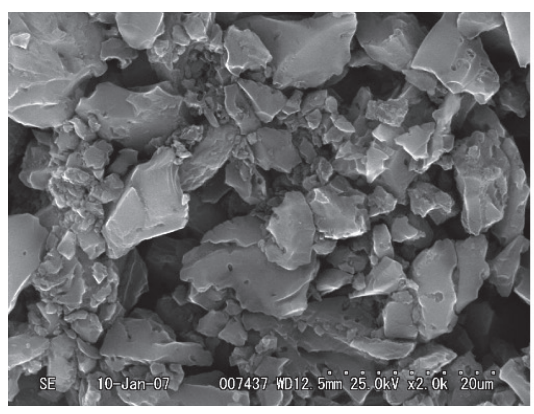

(a)

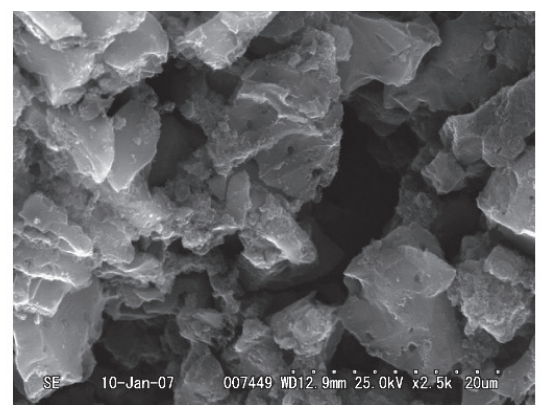

(b)

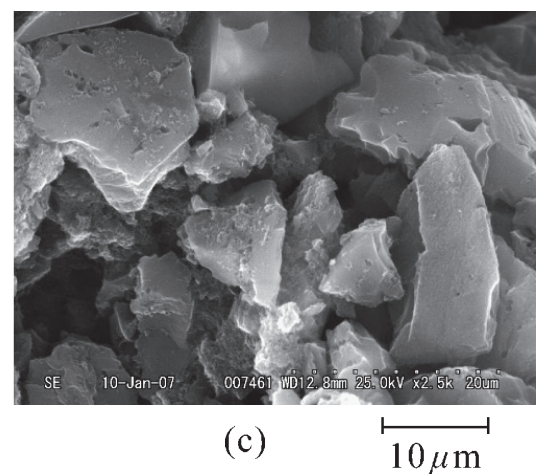

(c)

$10 \mu \mathrm{m}$

Fig.13 SEM images of the steam-activated carbon (AC) film. Deposition time: $60 \mathrm{~s}$. Concentration of AC powder in the bath: (a) $3.0 \mathrm{gl}^{-1}$, (b) $2.7 \mathrm{~g} \mathrm{l}^{-1}$, (c) $2.1 \mathrm{~g}^{-1}$, concentration of KB powder in the bath: (b) and (c) $0.3 \mathrm{~g} \mathrm{l}^{-1}$, concentration of PVdF in the bath: (c) $0.6 \mathrm{gl}^{-1}$.

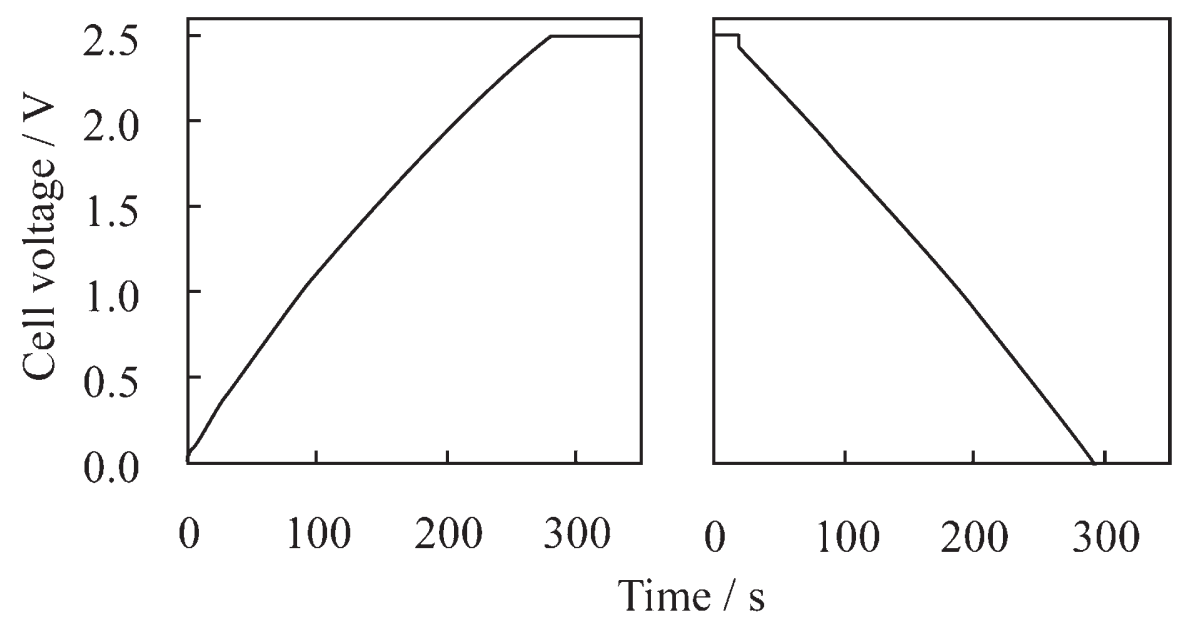

Fig.14 Charge-discharge curves of the co-deposited film electrode prepared by the EPD method at $25^{\circ} \mathrm{C}$ (amount of deposit: $5.99 \mathrm{mg} \mathrm{cm}{ }^{-2}$ ). Current density: $0.2 \mathrm{~A} \mathrm{~g}^{-1}$. 
夕電池に用いられているシート電極の容量 $\left(24.7 \mathrm{Fg}^{-1}\right.$ (- シー 卜電極全体の質量))にほぼ匹敵する值である，以上の結果， 泳動電着法で作製した共析膜は, キャパシ夕電池用電極とし て十分作動することが明らかとなった。

\section{5 おわりに}

以上のように, 泳動電着法を用いた炭素材料膜の作製は可 能であり, リチウムイオン二次電池用黒鉛負極とキャパシタ 電池用電極として作動することが示された．また，泳動電着 法は高機能性材料膜を作製できるだけでなく, 低コストで低 環境負荷な製造プロセス技術としての可能性も秘めている. そのため, 製造プロセス技術としての導入が進めば，産業界 における低コスト化・省エネルギー化に貢献できるものと期 待している.

\section{謝 辞}

本研究の一部は, 文部科学省科学研究費補助金 (若手研究 (B), 課題番号 15750158) の助成によったことを付記し, 謝意 を表します。

\section{文献}

1) F.F.Reuss: "Sur un Nouvel Effet de l'électricité Galvanique", Mem. Soc. Imp. Natur. Moscou, 2(1809)327-337.

2) Y.Tokuoka, T.Kishi and T.Nagai: "Electrophoretic Deposition of Nickel Ferrite Particles Dispersed in Acetone", Denki Kagaku (Electrochemistry), 42(1974) 80-84.

3) N.Koura and Y.Mikuriya: "Superconducting Oxides Coating on Ceramics", J. Surf. Finish. Soc., Jpn., 40(1989) 819-824.

4) N.Koura, T.Tsukamoto, H.Shoji and T.Hotta: "Preparation of Various Oxide Films by the Electrophoretic Deposition Method-A Study of the Mechanism", Jpn. J. Appl. Phys., 34 (1995) 1643-1647.

5) J.Mizuguchi, K.Sumi and T.Muchi: "A Highly Stable Nonaqueous Suspension for the Electrophoretic Deposition of Powdered Substances", J. Electrochem. Soc., 130(1983)18191825 .

6) H.Negishi, N.Koura, Y.Idemoto and M.Ishikawa: "Preparation of Tl-2223 Superconducting Coating by Electrophoretic Deposition Method", Jpn. J. Appl. Phys., 35(1996)4302-4306.

7) F.Beck and H.Guder: "Electrodeposition of Paint in Carbon Black Filled Systems", J. Electrochem. Soc., 134(1987)24162424.

8) P.V.Kamat, S.Barazzouk, K.G.Thomas and S.Hotchandani: "Electrodeposition of $\mathrm{C}_{60}$ Cluster Aggregates on Nanostructured $\mathrm{SnO}_{2}$ Films for Enhanced Photocurrent Generation", J. Phys. Chem. B, 104(2000)4014-4017.

9) H.Hotta, S.Kang, T.Umeyama, Y.Matano, K.Yoshida, S.Isoda and H.Imahori: "Effects of Fullerene Substituents on Structure and Photoelectrochemical Properties of Futlerene Nanoclusters
Electrophoretically Deposited on Nanostructured $\mathrm{SnO}_{2}$ Electrodes", J. Phys. Chem. B, 109(2005) 5700-5706.

10) W.B.Choi, Y.W.Jin, H.Y.Kim, S.J.Lee, M.J.Yun, J.H.Kang, Y.S.Choi, N.S.Park, N.S.Lee and J.M.Kim: "Electrophoresis Deposition of Carbon Nanotubes for Triode-type Field Emission Display", Appl. Phys. Lett., 78(2001)1547-1549.

11) C.Du, D.Heldbrant and N.Pan: "Preparation and Preliminary Property Study of Carbon Nanotubes Films by Electrophoretic Deposition", Mater. Lett., 57(2002)434-438.

12) T.Suzuki, T.Uchikoshi and Y.Sakka: "Control of Texture in Feeble Magnetic Ceramics by Using Colloidal Processing and a High Magnetic Filed", The 2nd Meeting on Tensorial Processing for Ceramics Using External Field, Abstr., T.Uchikoshi ed., Tokyo, Tokyo Metropolitan University, (2003)21-22.

13) T.Uchikoshi, T.Suzuki, H.Okuyama and Y.Sakka: "Texture Control of Ceramic Bodies by the Electrophoretic Deposition in a Strong Magnetic Filed", The 2nd Meeting on Tensorial Processing for Ceramics Using External Field, Abstr., T.Uchikoshi ed., Tokyo, Tokyo Metropolitan University, (2003) 23-24.

14) T.Kurosaki, A.Nakagawa, S.Iimura, S.Yoshihara and T.Shirakashi: "Photocatalytic Properties of Titanium Oxide Coating Prepared by Electrophoretic Sol-Gel Deposition", Electrochemistry, 70(2002)860-862.

15) S.J.Limmer, S.Seraji, Y.Wu, T.P.Chou, C.Nguyen and G.Z.Cao: "Template-Based Growth of Various Oxide Nanorods by SolGel Electrophoresis", Adv. Funct. Mater., 12(2002)59-64.

16) K.Kanamura, A.Goto, J.Hamagami and T.Umegaki: "Electrophoretic Fabrication of Positive Electrodes for Rechargeable Lithium Batteries", Electrochem. Solid-State Lett., 3(2000)259-262.

17) K.Kanamura, A.Goto, Y.H.Rho and T.Umegaki: "Electrophoretic Fabrication of $\mathrm{LiCoO}_{2}$ Positive Electrodes for Rechargeable Lithium Batteries", J. Power Source, 97-98 (2001)294-297

18) J.Hamagami, K.Kanamura and T.Umegaki: "Fabrication of Electrodes for Rechargeable Lithium Batteries by Using Electrophoretic Deposition Process", Materials Integration, 13 (2000)63-68.

19) J.Hamagami and K.Kanamura: "Innovation of Material Processing by Using Electrophoretic Deposition Method", J. Soc. Powder Technol. Jpn., 39(2002)587-594.

20) Y.Takayama, N.Koura, Y.Idemoto, H.Yanagishita, T.Nakane, M.Kawamura and N.Tanabe: "Preparation of Zeolite Films Using Electrophoretic Deposition Method", J. Ceram. Soc. Jpn., 107(1999)437-441.

21) Y.Idemoto, S.Yoshida, K.Ui and N.Koura: "Preparation of $\mathrm{Pb}-\mathrm{Zr}$-Ti-Nb-Si-O Ferroelectric Thick Film by Electrophoretic 
Deposition", Electrochemistry, 74(2006)883-889.

22) M.Yoshio and A.Kozawa: "Lithium-ion Secondary Battery -Material and Application-", The Nikkan Kogyo Shimbun, Ltd., (1996) 153-156.

23) R.Fong, U.V.Sacken and J.R.Dahn: "Studies of Lithium Intercalation into Carbons Using Nonaqueous Electrochemical Cells", J. Electrochem. Soc., 137(1990) 2009-2013.

24) K.Suzuki, T.Hamada and T.Sugiura: "Effect of Graphite Surface Structure on Initial Irreversible Reaction in Graphite Anodes", J. Electrochem. Soc., 146(1999)890-897.

25) K.Zaghib, G.Nadeau and K.Kinoshita: "Effect of Graphite Particle Size on Irreversible Capacity Loss", J. Electrochem. Soc., 147(2000)2110-2115.

26) K.Izutsu: "Hisuiyouekinodenkikagaku", Baifukan Co., Ltd.,
(1995).

27) N.Koura, S.Funo, H.Tsuiki, Y.Idemoto, K.Ui and F.Matsumoto: "Fabrication of Carbon Anode for Li-ion Secondary Batteries Prepared by Electrophoretic Deposition Method", J. Surf. Finish. Soc., Jpn., 53(2002)683-687.

28) K.Ui, T.Minami, K.Ishikawa, Y.Idemoto and N.Koura: "Development of Nonflammable Lithium Secondary Battery with Ambient-Temperature Molten Salt Electrolyte: Performance of binder-free carbon-negative electrode", J. Power Sources, 146(1-2)(2005)698-702.

29) K.Ui, K.Okura, N.Koura, S.Tsumeda and K.Tamamitsu: "Fabrication of Electrode for Capacitor Cell Prepared by Electrophoretic Deposition Method", Electrochemistry, 75 (2007) 576-578. 